\title{
SH2D3A wt Allele
}

National Cancer Institute

\section{Source}

National Cancer Institute. SH2D3A wt Allele. NCI Thesaurus. Code C52417.

Human SH2D3A wild-type allele is located in the vicinity of 19p13.3 and is approximately $15 \mathrm{~kb}$ in length. This allele, which encodes $\mathrm{SH} 2$ domain-containing protein 3A, may be involved in the regulation of both growth factor and cellular adhesion-mediated signaling cascades. 